Volume 3

\title{
The Risks of Clouded Property Title for Cannabis Business Owners, Investors, and Creditors
}

Sean M. O'Connor

University of Washington School of Law (Seattle)

Jason Liu

University of Wash-ington School of Law (Seattle)

Follow this and additional works at: https://scholarship.law.tamu.edu/journal-of-property-law

Part of the Medical Jurisprudence Commons

\section{Recommended Citation}

Sean M. O'Connor \& Jason Liu, The Risks of Clouded Property Title for Cannabis Business Owners, Investors, and Creditors, 3 Tex. A\&M J. Prop. L. 67 (2018).

Available at: https://doi.org/10.37419/JPL.V3.11.3

This Symposia Article is brought to you for free and open access by Texas A\&M Law Scholarship. It has been accepted for inclusion in Texas A\&M Journal of Property Law by an authorized editor of Texas A\&M Law Scholarship. For more information, please contact aretteen@law.tamu.edu. 


\title{
The Risks of Clouded Property Title for Cannabis Business Owners, Investors, and Creditors
}

\author{
Sean M. O'Connor † \\ Jason Liuł
}

\begin{abstract}
This Article provides a brief primer on the surprising range of assets that the CSA forfeiture provisions govern for the state-legal cannabis businesses. It outlines these provisions for tangible as well as intangible property, with an emphasis on risks to state-legal cannabis businesses' intellectual property and issued securities. We argue that these forfeiture risks create clouded title for all subject tangible and intangible property - not only for the state-legal businesses and their proprietors, but also for those businesses' outside investors, creditors, and suppliers/contractors.
\end{abstract}

I. Introduction................................ 67

II. The CSA's Forfeiture Provisions . . . . . . . . . . . . . 69

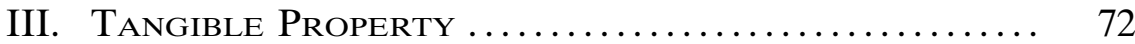

IV. Intangible Property ............................ 74

A. Intellectual Property........................ 75

1. Federal Intellectual Property $\ldots \ldots \ldots \ldots \ldots \ldots . \quad 75$

2. State Intellectual Property $\ldots \ldots \ldots \ldots \ldots \ldots \ldots . \quad 81$

B. Securities .............................. 83

V. Implications of Clouded Title for Cannabis Business Owners, Investors, and Creditors .......

\section{INTRODUCTION}

Even as Washington State, Colorado, and now Oregon and Alaska, have "state-legal" cannabis businesses, there are so many ways in which these businesses are anything but ordinary. The effects of cannabis's remaining under Schedule 1 of the Controlled Substances Act ("CSA") ${ }^{1}$ - and thus illegal to manufacture, distribute, or dispense (or possess with intent to manufacture, distribute, or dispense) ${ }^{2}$ - have been unexpectedly far-reaching. Few banks will open cannabis busi-

$\dagger$ Boeing International Professor and Faculty Director, Cannabis Law \& Policy Project, University of Washington School of Law (Seattle). The Authors thank the staff of the Journal for hosting the Symposium and excellent editorial support in the publication of this Article. All errors are the Authors' own.

\$ Student and Cannabis Law \& Policy Project Researcher, University of Washington School of Law (Seattle).

1. Controlled Substances Act, Pub. L. No. 91-513, 84 Stat. 1242 (Oct. 27, 1970) (codified at 21 U.S.C. $\S \S 801$ et. seq.).

2. 21 U.S.C. $\S 841$ (2012).

DOI: https://doi.org/10.37419/JPL.V3.I1.3 
ness accounts, ${ }^{3}$ resulting in the dangers of all-cash businesses moving substantial amounts of money. Federal bankruptcy courts will not take on insolvent cannabis businesses for fears of being involved in drug transactions if the courts mandate the transfer of cannabis product, or even just aiding and abetting criminal activity (including money laundering) by allocating other assets of cannabis businesses. ${ }^{4}$ Thus, even as the aforementioned states seek to regulate and normalize cannabis business markets, they are faced with knotty legal issues arising from the federal-state tension over cannabis that might derail such efforts.

One such issue that has received insufficient attention in the legal academic literature is the forfeiture rules under the CSA. ${ }^{5}$ Fans of Miami Vice, and other television shows or movies focused on law enforcement and drug producers and dealers, will be quite familiar with the notion that agents and prosecutors can seize not only the illicit drugs themselves, but also weapons, luxuries, and other assets of the bad guys. ${ }^{6}$ Slick yachts and cars are memorable law enforcement targets if they can be tangentially linked with CSA violations. ${ }^{7}$ But actually, such property can be seized even if it was simply obtained as the proceeds of the illegal acts, or derived from those proceeds. ${ }^{8}$ But because federal law does not distinguish between shadowy underworld drug deals and the clean, well-lit places licensed and regulated under the new state-legal regimes, all of the forfeiture rules apply equally to both. Accordingly, the facade of legitimacy and regularity rapidly attaching to the most well-intentioned state-legal cannabis businesses is, of course, quite illusory. And while many observers understand that all of these businesses and their proprietors and employees run the risk of federal prosecution, it is not clear whether enough of those businesses-or their investors, suppliers, and creditors-realize that all property owned by or related to these businesses is subject to seizure and forfeiture.

This Article provides a brief primer on the surprising range of assets that the CSA forfeiture provisions govern, even for the state-legal cannabis business. It proceeds by outlining the CSA and its forfeiture provisions in Part II. Tangible property in the form of real property and personal property is analyzed in Part III. Intangible property in

3. Jeremy Berke, This could be the No. 1 problem facing legal weed businesses in America, Bus. Insider (Nov. 12, 2015, 4:46 PM), http://www.businessinsider.com/ americas-marijuana-companies-cant-put-money-in-banks-2015-11.

4. See Casey C. Sullivan, Colorado Marijuana Businesses Barred From Bankruptcy Court, FIndLaw (Sept. 3, 2015, 2:36 PM), http://blogs.findlaw.com/ tenth_circuit/2015/09/colorado-marijuana-businesses-barred-from-bankruptcycourt.html.

5. $\$ 853$.

6. Miami Vice, WIKIPEDIA, https://en.wikipedia.org/wiki/Miami_Vice (last visited Apr. 17, 2016) (showing series creator Anthony Yerkovich created the concept after learning about asset forfeiture as applied to bolster law enforcement).

7. $\S 853(a)(2)$.

8. $\S 853(\mathrm{a})(1)$. 
the form of intellectual property and securities is analyzed in Part IV. The Conclusion sums up the risks of clouded title that these forfeiture provisions impose on not only state-legal businesses and their proprietors, but also for outside investors, creditors, and suppliers/ contractors.

\section{The CSA's Forfeiture Provisions}

The CSA, passed in 1970, consolidated various federal drug laws into a cohesive system of regulations. The system created "Schedules," or classifications of controlled substances with different levels of regulation. ${ }^{9}$ The most restrictive level, "Schedule I," was reserved for drugs or substances that have: 1) a high potential for abuse; 2) no currently accepted medical use or treatment potential in the United States; and 3) lack accepted safe use for the drug or other substance under medical supervision. ${ }^{10}$ "Marihuana" 11 was placed into Schedule I. ${ }^{12}$

For Schedule I drugs and substances, the CSA prohibits their manufacture, distribution, or dispensation, as well as their possession with intent to manufacture, distribute, or dispense. ${ }^{13}$ Penalties for such acts include not only fines and imprisonment,${ }^{14}$ but also both criminal and civil forfeiture of various enumerated property to the United States. ${ }^{15}$ Criminal forfeiture can occur where individuals have violated CSA provisions punishable by more than one year in prison. ${ }^{16}$ Such forfeiture applies to:

(1) any property constituting, or derived from, any proceeds the person obtained, directly or indirectly, as the result of such violation;

(2) any of the person's property used, or intended to be used, in any manner or part, to commit, or to facilitate the commission of, such violation; and

(3) in the case of a person convicted of engaging in a continuing criminal enterprise in violation of section 848 of this title, the person shall forfeit, in addition to any property described in paragraph (1)

9. $\S 812$.

10. $\S 812(\mathrm{~b})(1)$.

11. "The term "marihuana" means all parts of the plant Cannabis sativa L., whether growing or not; the seeds thereof; the resin extracted from any part of such plant; and every compound, manufacture, salt, derivative, mixture, or preparation of such plant, its seeds or resin. Such term does not include the mature stalks of such plant, fiber produced from such stalks, oil or cake made from the seeds of such plant, any other compound, manufacture, salt, derivative, mixture, or preparation of such mature stalks (except the resin extracted therefrom), fiber, oil, or cake, or the sterilized seed of such plant which is incapable of germination." 21 U.S.C. § 802(16) (2012).

12. $\$ 812$ (c) (Schedule I, item (c)(10)).

13. $\S 841(\mathrm{a})$.

14. $\$ 841(\mathrm{~b})$.

15. $\S 8853,881$.

16. $\S 853(a)$. 
or (2), any of his interest in, claims against, and property or contractual rights affording a source of control over, the continuing criminal enterprise. ${ }^{17}$

"Property" for purposes of such criminal forfeiture is defined to include:

(1) real property, including things growing on, affixed to, and found in land; and

(2) tangible and intangible personal property, including rights, privileges, interests, claims, and securities. ${ }^{18}$

Criminal forfeiture is also governed by the civil forfeiture provisions of Section 881, to the extent not inconsistent with Section 853. ${ }^{19}$ Civil forfeiture generally turns on the nature of the property, or its actual or intended uses. The following kinds of property are subject to seizure and "no property right shall exist in them" by statutory provision:

(1) All controlled substances which have been manufactured, distributed, dispensed, or acquired in violation of this subchapter.

(2) All raw materials, products, and equipment of any kind which are used, or intended for use, in manufacturing, compounding, processing, delivering, importing, or exporting any controlled substance or listed chemical in violation of this subchapter.

(3) All property which is used, or intended for use, as a container for property described in paragraph (1), (2), or (9).

(4) All conveyances, including aircraft, vehicles, or vessels, which are used, or are intended for use, to transport, or in any manner to facilitate the transportation, sale, receipt, possession, or concealment of property described in paragraph (1), (2), or (9).

(5) All books, records, and research, including formulas, microfilm, tapes, and data which are used, or intended for use, in violation of this subchapter.

(6) All moneys, negotiable instruments, securities, or other things of value furnished or intended to be furnished by any person in exchange for a controlled substance or listed chemical in violation of this subchapter, all proceeds traceable to such an exchange, and all moneys, negotiable instruments, and securities used or intended to be used to facilitate any violation of this subchapter.

(7) All real property, including any right, title, and interest (including any leasehold interest) in the whole of any lot or tract of land and any appurtenances or improvements, which is used, or intended to be used, in any manner or part, to commit, or to facilitate the commission of, a violation of this subchapter punishable by more than one year's imprisonment.

(8) All controlled substances which have been possessed in violation of this subchapter.

(9) All listed chemicals, all drug manufacturing equipment, all tableting machines, all encapsulating machines, and all gelatin cap-

17. 21 U.S.C. $\S 853(a)(2012)$.

18. $\S 853(b)$.

19. $\S 853(\mathrm{j})$. 
sules, which have been imported, exported, manufactured, possessed, distributed, dispensed, acquired, or intended to be distributed, dispensed, acquired, imported, or exported, in violation of this subchapter or subchapter II of this chapter.

(10) Any drug paraphernalia (as defined in section 863 of this title). (11) Any firearm (as defined in Section 921 of Title 18) used or intended to be used to facilitate the transportation, sale, receipt, possession, or concealment of property described in paragraph (1) or (2) and any proceeds traceable to such property. ${ }^{20}$

Once seized, all right, title, and interest to such property is vested in the United States by statute. ${ }^{21}$

In the wake of Colorado's and Washington State's respective initiatives to state-legalize recreational cannabis, the U.S. Department of Justice ("DOJ") took a cautious response. Rather than taking any direct action against the states or officials within them tasked with implementing the recreational systems, the DOJ instead issued an internal guidance memo to U.S. attorneys. Popularly called the Cole Memo after its author, U.S. Deputy Attorney James M. Cole, the document recommended that U.S. attorneys use a set of drug enforcement priorities in deciding where and how to allocate limited government resources to cannabis prosecutions. ${ }^{22}$ The guidance was particularly directed to attorneys in states with "robust" state cannabis regulatory regimes. The eight priorities are:

(1) preventing the distribution of marijuana to minors;

(2) preventing revenue from the sale of marijuana from going to criminal enterprises, gangs, and cartels;

(3) preventing the diversion of marijuana from states where it is legal under state law in some form to other states;

(4) preventing state-authorized marijuana activity from being used as a cover or pretext for the trafficking of other illegal drugs or other illegal activity;

(5) preventing violence and the use of firearms in the cultivation and distribution of marijuana;

(6) preventing drugged driving and the exacerbation of other adverse public health consequences associated with marijuana use;

(7) preventing the growing of marijuana on public lands and the attendant public safety and environmental dangers posed by marijuana production on public lands; and

(8) preventing marijuana possession or use on federal property. ${ }^{23}$

State regulatory regimes, such as that of Washington State, were set up expressly to avoid tripping any of these eight prosecution priorities,

20. $\S 881(\mathrm{a})$.

21. $\S 881(\mathrm{~h})$.

22. Memorandum from U.S. Dep't of Justice, Office of the Deputy Attorney Gen., on Guidance Regarding Marijuana Enforcement (Aug. 29, 2013) [hereinafter Cole Memo II], http://www.justice.gov/iso/opa/resources/305201382913275 6857467.pdf.

23. Id. 
which also appeared in an earlier memo issued by Cole. ${ }^{24}$ Presumably, if the DOJ has de-prioritized cannabis business activities outside of these eight triggers in robustly regulated state systems, then it will also not seek forfeiture of those businesses' properties. But none of this is certain. At the same time, a rider to an appropriations bill in Congress last year prohibited the DOJ from using any congressionally appropriated funds for cannabis prosecutions for businesses or individuals operating under robust state regulatory systems. ${ }^{25}$ Notwithstanding this prohibition, the DOJ continued its prosecution of a California dispensary until a federal judge recently harshly rebuked the DOJ's theory of why its actions were not technically a use of appropriated funds. ${ }^{26}$ While this ruling might seem to be a major victory for regulated cannabis businesses, the DOJ's willingness to go to court to protect its ability to prosecute cannabis CSA violations, regardless of both the guidance of the Cole Memo and the Congressional appropriations bill, suggests that the DOJ is not quite ready to give up cannabis enforcement.

Accordingly, the prospect of both criminal and civil forfeiture is very much a live issue for cannabis businesses. The DOJ can retract or supersede the Cole Memo at any time, and Congress may decline to renew the appropriations restriction with sunsets by its own terms. Further, a new presidential administration will take office in January 2017 and will set its own cannabis policy, which could be looser or stricter than the Cole Memo under the current Obama Administration.

\section{TAngible Property}

For purposes of our analysis here, we will divide property subject to forfeiture into two categories: tangible and intangible. In this Part we consider tangible property. Such property is broken into two further categories of real property and personal property.

The CSA provides law enforcement agencies broad discretion in the taking of land in proportion to the CSA violation. Courts have interpreted the statute to allow forfeiture of entire tracts of land even when CSA violations occurred on only part of the land or when the comparative worth of the drugs found was minimal. In United States $v$. 40 Moon Hill Road, the court held that an entire tract of property was

24. Memorandum of U.S. Dep't of Justice, Office of the Deputy Attorney Gen., on Guidance Regarding the Ogden Memo in Jurisdictions Seeking to Authorize Marijuana for Medical Use (June 29, 2011), https://www.justice.gov/sites/default/files/oip/ legacy/2014/07/23/dag-guidance-2011-for-medical-marijuana-use.pdf.

25. Consolidated and Further Continuing Appropriations Act, H.R. 83, 113th Cong. $\S 538$ (2014) (prohibited the Department of Justice to use funds from the act to prevent states from implementing medical marijuana frameworks).

26. United States v. Marin All. for Med. Marijuana, No. C 98-00086 CRB, 2015 WL 6123062, at *4 (N.D. Cal. Oct. 19, 2015), appeal filed, No. 15-17486 (9th Cir. Dec. 21, 2015). 
forfeitable despite the fact that the marijuana-growing operation took place on only portions of the land. ${ }^{27}$ Furthermore, the land's worth was in excess of the worth of the cannabis articles that were seized.

Forfeiture of real property has also been allowed when the drugs were intended for personal use. In United States v. 250 Kreag Road, the court held that growing marijuana for personal medical use meets the CSA's forfeiture requirements. ${ }^{28}$ The court also rejected an argument that forfeiture constitutes cruel and unusual punishment. ${ }^{29}$ Other courts have rejected arguments that the provision is unconstitutionally vague. ${ }^{30}$

However, the forfeiture provision does establish an "innocent owner" defense, contingent on an owner's subjective lack of knowledge or consent. ${ }^{31}$ For example, property lessors may qualify for the defense where they did not consent to the applicable CSA violations occurring on the property or by taking action against it. ${ }^{32}$ However, other lessors have been precluded from using the defense when they failed to establish that they lacked knowledge of the CSA violations occurring on their properties, ${ }^{33}$ or consented to them by not taking action. ${ }^{34}$

With regard to personal property, federal courts have predominantly upheld seizure and forfeiture actions by the government. ${ }^{35}$ But the range of types of property that may be seized might be surprising. Essentially all kinds of property that might be related to the prohibited activities are included. ${ }^{36}$ Certainly any controlled substances and raw materials used to produce them can be seized. Beyond this, all manner of business assets can also be seized: property that can be used as containers for controlled substances; all conveyances including aircraft, vehicles, or vessels used to transport controlled substances or facilitate the prohibited activities; books, records, microfilm, and tapes used to violate the CSA; moneys related to controlled substances transactions or derived therefrom; all drug manufacturing equipment,

27. United States v. 40 Moon Hill Rd., 884 F.2d 41, 45 (1st Cir. 1989).

28. United States v. 250 Kreag Rd., 739 F. Supp. 120, 124 (W.D.N.Y 1990).

29. Id. at $124-25$.

30. United States v. Santoro, 866 F.2d 1538, 1542 (4th Cir. 1989).

31. United States v. 2511 East Fairmont Ave., 722 F. Supp. 1273, 1281 (D. Md. 1989).

32. United States v. 141st St. Corp., 911 F.2d 870, 878 (2d Cir. 1990); United States v. 418 57th Street, 922 F.2d 129, 130 (2d Cir. 1990).

33. United States v. 2011 Calumet, 699 F. Supp. 108, 110 (S.D. Tex. 1988).

34. 141st St. Corp., 911 F.2d at 879.

35. See, e.g., United States v. $\$ 10,000.00$ in U.S. Currency, 348 F. Supp. 2d 612 (M.D.N.C. 2004) (requirement of probable cause showing of substantial connection between the property forfeited and criminal activity); United States v. One 1975 Lincoln Cont'l, 72 F.R.D. 535 (S.D.N.Y. 1976) (vehicle forfeited in connection with drug trafficking); United States v. U.S. Currency, \$30,060.00, 39 F.3d 1039 (9th Cir. 1994) (forfeiture of currency related to drug transactions).

36. 21 U.S.C. $\S 881(\mathrm{a})(2012)$. 
tableting machines, encapsulating machines, and gel capsules; and firearms used or intended to be used to facilitate prohibited activities. ${ }^{37}$

Given the modern high-tech nature of cannabis products-especially in the categories of edibles, vaping, sublinguals, and extracts ${ }^{38}$ cannabis businesses may have significant capital assets subject to forfeiture. In other words, the cannabis industry today is far different from the Cheech and Chong days of mellow stoners smoking joints. ${ }^{39}$ Back then, production equipment often constituted only some grow lamps, potting and gardening materials, scales, rolling papers and baggies, and, of course, L.P. album covers or other suitable flat surfaces for separating out seeds. ${ }^{40}$ By contrast, today's most cutting-edge production facilities look more like sophisticated biotech or chemistry labs than Cheech and Chong's crash pad. ${ }^{41}$ And the investment capital required to equip these labs is likewise significant. ${ }^{42}$ Yet all of it is funded, used, and accounted for on balance sheets under what can only be construed as clouded title. The federal government can come in at any time and, for no other reason than that the equipment is being used in that state-legal cannabis business, seize the assets with no compensation. ${ }^{43}$ The owners are deemed to have no property rights in the equipment and, in fact, all rights, title, and interest vest in the United States. ${ }^{44}$

\section{Intangible Property}

Beyond the more obvious tangible property subsisting in cannabis businesses' raw materials, inventory, capital assets, and real estate, today's state-legal cannabis growers and processors are increasingly focused on intangible properties. These include two major categories: intellectual property for product and process inventions, trademarks for brands and packaging, and copyright for written materials; and securities for investment capital including stock, convertible notes, and

37. $I d$.

38. What Type of Cannabis Therapy Is Best for You?, Project CBD, https:// www.projectcbd.org/what-type-cannabis-therapy-best-you (last visited Apr. 17, 2016).

39. CHEECH AND CHONG, CHEech \& CHONG, http://cheechandchong.com/ bio (last visited Apr. 17, 2016).

40. See generally Danny Danko, Cannabis Cultivation Basics, HIGH TIMES (Dec. 26, 2013), http://www.hightimes.com/read/cannabis-cultivation-basics; see generally GHUA, Using vinyl covers for cleaning pot?, INT'L CANNAGRAPHIC (May 7, 2010, 9:54 PM), https://www.icmag.com/ic/showthread.php?t=172286.

41. Greg James, Suspended Brands: The Cutting Edge of Technology, MariJuana Venture (Apr. 7, 2016), http://www.marijuanaventure.com/suspended-brands-cutting-edge-technology/.

42. See Calum Marsh, Five tips for growing and selling marijuana like a pro - from a university instructor, THE GUARDIAN (Aug. 25, 2015, 9:30 PM), http:// www.theguardian.com/society/2015/aug/25/five-tips-growing-selling-marijuana.

43. See 21 U.S.C. $\S 881$ (2012).

44. $\S 881(\mathrm{a}),(\mathrm{h})$. 
other hybrid debt-equity instruments. This Part shows how these intangible properties are also subject to seizure and forfeiture under the CSA.

\section{A. Intellectual Property}

Intellectual property ("IP") is covered by a mix of federal and state statutes and state common law rights. While federal rights may seem most valuable-because of presumptive nation-wide coverage and automatic access to federal courts-state trademark rights have seen a new level of interest in the cannabis industry. ${ }^{45}$ This is because the United States Patent and Trademark Office ("USPTO") is not registering cannabis trademarks while state residency requirements for state-legal cannabis licensees in states like Washington mean that outof-state holding trademark rights in other jurisdictions cannot enforce them in state as a practical matter ${ }^{46}$ This Section considers first federal IP rights in the cannabis and CSA context, and then turns to state rights.

\section{Federal Intellectual Property}

Patents and copyrights are presently, as a practical matter, exclusively the province of federal statutory law. ${ }^{47}$ Trademarks are a mixed system of federal and state rights. ${ }^{48}$ Trade secrets are almost exclu-

\footnotetext{
45. See Sean K. Clancy, Branded Bud or Generic Ganja? Trademarks for Marijuana in Washington, 18 LewIS \& ClARK L. REv. 1063, 1082-1084 (2014).

46. Jennifer Visintine, Branding your bud: Why trademarks are tricky for marijuana businesses, ThOMPSON COBURN LLP (Aug. 27, 2015) http://www.thompsonco burn.com/news-and-information/cannabis-blog/blog/15-08-27/branding-your-budwhy-trademarks-are-tricky-for-marijuana-businesses.aspx.

47. Technically, states may still have the authority to issue patents, so long as those grants do not interfere with the federal system. Early nineteenth century cases expressly left this issue open. Gibbons v. Ogden, 22 U.S. 1 (1824), a seminal case involving state patents, was actually decided on Commerce Clause grounds because of the effect of the New York State issued patents on shipping in interstate commerce (e.g., to New Jersey). It did not resolve the issue of whether states could continue to grant patents after enactment of the first federal Patent Act in 1790, so long as those patents did not directly interfere with interstate commerce. Notwithstanding, no states currently issue utility patents. Further, there is an argument that a Supreme Court decision establishing a channeling of rights and powers as between state trade secret systems and the federal patent regime implicitly prohibits states from issuing patents as those would conflict with federal patents. See, e.g. Kewanee Oil v. Bicron Corp., 416 U.S. 470, 472 (1974). On the copyright side, up until the 1976 Copyright Act, federal law expressly left copyright for unpublished works to the states. However, that Act abolished the distinction and therefore all copyrighted works created after the effective date of the Act are exclusively governed by federal law. Pre-1976 Act copyrights on unpublished works remain in force under the terms of the state rights until they expire by those terms. The 1976 Act appears to signal Congress' intent to preempt the field for federal pre-emption purposes, and so it is unlikely that any concurrent power to grant copyright protection is left to the states.

48. While Congress was directly authorized under the IP Clause of the U.S. Constitution to create exclusive rights for writings and discoveries to authors and inventors (generally deemed to mean copyright and patent systems), U.S. ConsT. art. I, § 8,
} 
sively state rights, with the limited exception of some protections available under the federal Economic Espionage Act. ${ }^{49}$ This Subsection covers the federal IP rights of patents, trademarks, and copyright.

Intriguingly, the USPTO, which as its name suggests covers both the federal patent and trademark systems, is currently divided internally on whether cannabis businesses should be able to secure federal IP rights. On the patent office side, patents are being issued for methods involving cannabinoids and for paraphernalia products. ${ }^{50}$ But on the trademark office side, registrations are being refused for any cannabis, marijuana, or related marks when they are to be used in a cannabis business.

Even more fascinating, the U.S. Department of Health and Human Services is the assignee of U.S. Patent Number 6,630,507, "Cannabinoids as Antioxidants and Neuroprotectants." ${ }^{51}$ The patent covers methods of using cannabinoids with no psychoactive component to minimize tissue damage in patients who have diseases caused by oxidative stress, such as autoimmune diseases. But it is hardly the only cannabis patent issued by the USPTO. Also cited by this patent are U.S. Patent Numbers 5,538,993, 5,521,215, 5,284,867, and 5,434,295, which cover uses of variants of THC or its homologs. 52

With regard to cannabis paraphernalia, the USPTO has issued Patent Number 4,216,785 on "an improved smoking . . pipe or bong." Likewise this is not the only patent in its class, much less for paraphernalia generally. U.S. Patent Numbers 3,882,875 and 3,881,499 also

cl. 8, that Clause was held to not extend to trademarks. When Congress first sought to create a federal trademark system in the late nineteenth century it passed an act that would have given the federal government exclusive trademark authority under the IP Clause. This was successfully challenged in In re Trade-Mark Cases, 100 U.S. 82 (1879), in which the Supreme Court held that the IP Clause did not so authorize Congress. Thus, under the later Lanham Act, Pub. L. No. 79-489, 60 Stat. 427 (1946), Congress expressly tethered its trademark provisions to interstate commerce in order to exercise its authority under the Commerce Clause instead, U.S. Const. art. I, § 8, cl. 3. But this then explicitly left concurrent powers to the states for purely intrastate trademarks.

49. Many states have enacted a version of the Uniform Trade Secrets Act, see, e.g., WASH. Rev. CODE $§ 19.108$. But trade secrets can also be enforced under common law tort misappropriation theories. In 1996, the United States enacted the Economic Espionage Act particularly to cover trade secret theft by foreign nationals. Economic Espionage Act of 1996, Pub. L. No. 104-294, 110 Stat. 3488 (Oct. 11, 1996). A current bill in Congress would significantly extend the reach of federal trade secret law, while not appearing to fully pre-empt state law.

50. U.S. Patent No. 6,630,507 (filed Feb. 2, 2001); U.S. Patent No. 4,216,785 (filed Aug. 25, 1977).

51. '507 Patent.

52. Id.; see also U.S. Patent No. 5,538,993 (filed Feb. 7, 1994); see also U.S. Patent No. 5,521,215 (filed Feb. 7, 1994); see also U.S. Patent No. 5,284,867 (filed Apr. 8, 1992); see also U.S. Patent No. 5,434,295 (filed Feb. 7, 1994).

53. '785 Patent. 
cover water pipe/bong inventions. ${ }^{54}$ Of course, water pipe/bong patents can, and often are, drawn towards use with tobacco ${ }^{55}$ and "medicinal herbs," 56 such that the USPTO could plausibly claim that it was not issuing a patent for an invention used in illegal activities.

There is no requirement that patents be issued only for legal activities. While the "moral utility" doctrine still technically exists, it requires a high showing of the invention's being effectively fraudulent in nature and purpose, with no countervailing social benefit. ${ }^{57}$ In the most recent notable invocation of the doctrine, a beverage dispenser supply company challenged a patent for an invention wherein a transparent compartment that contained a batch of the beverage visible to customers was not the actual source of beverage dispensed to the customer. ${ }^{58}$ Instead, a hidden apparatus combined the component ingredients on the spot and then dispensed this freshly made beverage to the customer. While the invention admittedly had a deceptive component to it, the patent was not invalidated on moral utility grounds because that deception was essentially in the customer's best interest to minimize receiving an at best stale, and at worst contaminated or putrid drink. This also makes sense given that patents are merely "negative rights." 59 The patent owner can merely prevent others from making, using, or selling the invention; the issued patent gives no positive rights for the patent holder or anyone else to practice the invention. For example, a patent on a pharmaceutical gives its owner no right to distribute the drug where it has not yet been approved by the Food and Drug Administration ("FDA"). ${ }^{60}$ Following from this, an inventor is not required to currently use, have ever used, or ever plan to use an invention in order to file and receive patent protection. ${ }^{61}$ As long as the patent is written broadly enough to encompass a legitimate purpose or substance, the fact that the invention's use is illegal does not seem to prevent it from being patented. ${ }^{62}$

On the other hand, cannabis trademark registrations are currently being rejected by the USPTO. The federal Lanham Act provides pro-

54. U.S. Patent No. 3,882,875 (filed Sept. 20, 1973); U.S. Patent No. 3,881,499 (filed Sept. 11, 1973).

55. "499 Patent.

56. '785 Patent.

57. See, e.g., Juicy Whip, Inc. v. Orange Bang, Inc., 185 F.3d 1364, 1368 (Fed. Cir. 1999).

58. $I d$.

59. Richard H. Shear \& Thomas E. Kelley, A Researcher's Guide to Patents, 132(3) Plant Physiology 1127 (2003), http://www.ncbi.nlm.nih.gov/pmc/articles/ PMC526265/.

60. Benjamin N. Roin, Unpatentable Drugs and the Standards of Patentability, 87 Tex. L. Rev. 503, 565 (2009).

61. See generally General Information Concerning Patents, USPTO (Oct. 2014), $\mathrm{http}: / /$ www.uspto.gov/patents-getting-started/general-information-concerning-patents \#heading-24.

62. See generally What Can Be Patented, USPTO (Oct. 2014), http:// www.uspto.gov/patents/resources/general_info_concerning_patents.jsp\#heading-4. 
tection for "any word, name, symbol, or device" used to identify and distinguish goods in commerce. ${ }^{63}$ Procedurally, an application for trademark requires the applicant to: 1) list the goods on which the mark is used, ${ }^{64}$ 2) the classification of the goods, ${ }^{65}$ and 3) the date on which the merchant first used the trademark in commerce in association with the goods or services. ${ }^{66}$ Importantly, a merchant's use of the trademark must be in lawful commerce. ${ }^{67}$ Since the CSA clearly prohibits the sale of cannabis, the USPTO has taken the position that any commerce involving cannabis is unlawful, even under state-legal regimes. A brief review of cannabis-product trademark applications bears this out. ${ }^{68}$

However, the USPTO has allowed registrations for trademarks used on ancillary goods and services related to cannabis products. ${ }^{69}$ For these registrations, the USPTO examiner has required applicants to "submit a written statement indicating whether the goods and/or services identified in the application comply with the Controlled Substances Act."70 Failure to comply with the examiner's requirements

63. 15 U.S.C $\S 1127$ (2012).

64. 37 C.F.R. $\S 2.32(a)(6)(2014)$.

65. $\S 2.32(\mathrm{a})(7)$.

66. 15 U.S.C. $§ 1051(\mathrm{a})(2)$.

67. TMEP § 907 (Apr. 2014 ed.); see also 37 C.F.R. § 2.69; see also CreAgri, Inc. v. USANA Health Scis., Inc., 474 F.3d 626, 630-31, 634 (9th Cir. 2007) (denying protection for a dietary supplement trademark, "Olivenol," because of federal labeling law violations).

68. See, e.g., U.S. Trademark Application Serial No. 77,654,053 (filed Jan. 22, 2009) ("MARIJUANA" application abandoned); U.S. Trademark Application Serial No. 86,054,742 (filed Sept. 3, 2013) ("WASHINGTON'S FINEST CANNABIS" application abandoned for "Marijuana, Marijuana Infused Products, Cannabis, Cannabis Infused Products").

69. Brett Trout, Marijuana Trademarks, BLAwgIT (July 27, 2010), http:// blawgit.com/2010/07/27/marijuana-trademarks/. For successful registrations see, e.g., MEDICAL MARIJUANA, Registration No. 4,024,120 ("[m]agazines about marijuana serving medicinal purposes"); MEDICAL CANNABIS CUP, Registration No. 4,259,895 ("[o]rganization and arrangement of educational and instructional seminars and conferences regarding legal, medical and political developments and societal attitudes about medical marijuana"); MJFREEWAY, Registration No. 4,330,124 ("[c]omputer services, namely, providing on-line non-downloadable web-based computer software for patient documentation and history, inventory control, and inventory management for use among medical marijuana centers, dispensaries, collectives, and patients"); BUDRUZ, Registration No. 4,550,100 ("[p]roviding a searchable online advertising website featuring the services of other vendors via the Internet, namely, featuring services of medical marijuana dispensaries"). For pending registrations, see, e.g., U.S. Trademark Application Serial No. 85,850,934 (filed Feb. 15, 2013) ("WOKE SMEED" notice of allowance issued for "[n]on-downloadable electronic publications in the nature of an online journal, namely, a blog in the field of the medicinal and recreational uses of marijuana").

70. See, e.g., WOKE SMEED, Registration No. 85,850,934; U.S. Trademark Application Serial No. 85,602,048 (filed Apr. 19, 2012); U.S. Trademark Application Serial No. 85,364,644 (filed July 6, 2011); U.S. Trademark Application Serial No. $85,727,284$ (filed Sept. 12, 2012). 
results in rejection. ${ }^{71}$ However, if an applicant attests to compliance with federal law, then registration is possible. ${ }^{72}$

A further potential barrier to federal registration is the prohibition on scandalous or immoral trademarks. A trademark examiner refused a trademark application for the mark "MARIJUANA" because the mark comprised immoral or scandalous matter ${ }^{73}$ Indeed, immoral or scandalous marks are ineligible for federal registration. ${ }^{74}$ But, this morality standard is unclear and depends on whether the mark is "shocking to the sense of truth, decency, or propriety; disgraceful, offensive; disreputable as scandalous conduct." 75 Whether a mark is scandalous or immoral is considered in relation to the goods and marketplace for which the mark is used. ${ }^{76}$ Morality is thus judged in through context of use and is a subjective process. ${ }^{77}$ Nonetheless, humorous or prurient subject matter can be registered. ${ }^{78}$ The morality standard is further complicated as indicated by the USPTO's willingness to register marijuana-related marks. ${ }^{79}$

Those contemplating less-than-fulsome disclosure to the USPTO about the intended use of a mark should realize that falsely representing that a mark is used in lawful commerce entails fraud upon the Trademark Office. ${ }^{80}$ This could result in various civil liabilities and

71. TMEP $\S 907$ (5th ed. Sept. 2007); see also rejected application U.S. Trademark Application Serial No. 85,602,048 (filed Apr. 19, 2012) ("REEFER MADNESS" published for opposition for "[e]ntertainment in the nature of an on-going special variety, news, music or comedy show featuring cannabis, hemp, pot, marijuana, 420, weed, mary jane broadcast over television, satellite, audio, and video media").

72. See, e.g., Response to Office Action (June 9, 2011), MEDICAL MARIJUANA, Registration Nos. 4,024,120 \& 4,133,282.

73. Supplemental Office Action (Oct. 12, 2006), U.S. Trademark Application Serial No. 78,401,566 (filed Apr. 14, 2004) ("MARIJUANA").

74. 15 U.S.C. § 1052(a) (2012); TMEP § 1203.01 (Apr. 2014 ed.).

75. In re McGinley, 660 F.2d 481, 486 (C.C.P.A. 1981) (emphasis omitted) (internal quotation marks omitted); see also In re Mavety Media Grp. Ltd., 33 F.3d 1367, 1371 (Fed. Cir. 1994).

76. In re Boulevard Entm't, Inc., 334 F.3d 1336, 1340 (Fed. Cir. 2003); see also In re Hepperle, 175 U.S.P.Q. (BNA) 512, 512 (T.T.A.B. 1972) (finding that "ACAPULCO GOLD" was not scandalous for use as suntan lotion, despite being a potential synonym for marijuana).

77. Theodore H. Davis, Jr., Registration of Scandalous, Immoral, and Disparaging Under Section 2(a) of the Lanham Act: Can One Man's Vulgarity Be Another's Registered Trademark?, 54 Оніо Sт. L.J. 331, 400 (1993).

78. Id. at 400-01.

79. See, e.g., MEDICAL MARIJUANA, Registration Nos. 4,024,120 \& 4,133,282 ("magazines about marijuana serving medicinal purposes"); search for Medical Cannabis Cup, Registration No. 4,259,895, Justia (2015), https://trademarks.justia.com/ 850/33/medical-cannabis-cup-85033340.html ("[o]rganization and arrangement of educational and instructional seminars and conferences regarding legal, medical and political developments and societal attitudes about medical marijuana").

80. 3 J. Thomas McCarthy, McCarthy on Trademarks and Unfair ComPETITION § 19:51 (4th ed. 2014); see also Fed. Treasury Enter. Sojuzplodoimport v. Spirits Int'l N.V., 425 F. Supp. 2d 458, 467-68 (S.D.N.Y. 2006). 
invalidation of the trademark registration. ${ }^{81}$ At any rate, regular marks are only enforceable within the class of goods or services they are registered under, and so this limits other creative approaches to get around the USPTO's current position to refuse registrations on cannabis products or service marks.

At the same time, a cannabis business could seek to bring a federal Lanham Act action under Section 43(a) on the basis of improper claims of affiliation or endorsement. ${ }^{82}$ Such actions are available even in the absence of a registered mark, and so the lack of a federal trademark registration would be no obstacle. ${ }^{83}$ However, it is unlikely that a federal court would grant relief under 43(a) for a cannabis business as it would be an implicit acceptance of the "legality" of the cannabis business or a use of federal instrumentalities to further such federally illegal activities, similar to the reluctance of federal bankruptcy courts to preside over cannabis business insolvency proceedings.

Copyright protections for works related to cannabis goods and services face little problems for federal registration. ${ }^{84}$ First, copyright registration by the Copyright Office is truly registration only-meaning that little to no examination of the registration occurs. ${ }^{85}$ At most, there may be a cursory check whether the submitted work is exactly identical to another registered work. ${ }^{86}$ But any real search is impossible at this point, given the volumes of registered copyrights, the length of copyright term (life of the author plus seventy years), ${ }^{87}$ and the fact that most of these works were registered based on analog or hard copy artifacts that are not electronically searchable. ${ }^{88}$ At any rate, this minimal check for literal copying is not focused on the nature of the work and so there would be no extra hurdle for works created by or for use with cannabis businesses. ${ }^{89}$

Central to our investigation here, though, is the fact that even when cannabis businesses secure federal patents, trademarks, or copyrights,

81. 15 U.S.C. $\$ 1120$ (2012); MCCARTHY, supra note 80; see TMEP § 720 (Apr. 2014 ed.).

82. 15 U.S.C. $§ 1125$.

83. Miller Brewing Co. v. Falstaff Brewing Corp., 503 F. Supp. 896, 905-906 (D.R.I. 1980) (stating that the Lanham Act "protects use of valid but unregistered trademarks").

84. Rebecca Gan, INTELLECTUAL PROPERTY LAW: Protection for Marijuana Trademarks, A.B.A. Vol. 32, No. 6 (Nov./Dec. 2015), http:// www.americanbar.org/publications/gp_solo/2015/november-december/

intellectual_property_law_protection_marijuana_trademarks.html.

85. See id.

86. See id.

87. U.S. Copyright Office, Duration of Copyright 1 (2011), http:// www.copyright.gov/circs/circ15a.pdf.

88. See Letter from Howard L. Berman, Member of Cong., to Marybeth Peters, Register of Copyrights (Jan. 10, 2005), in REGISTER OF COPYRIGHTS, U.S. COPYRIGHT OFFICE, REPORT ON ORPHAN WORKS 11 (2006), http://www.copyright.gov/orphan/orphan-report-full.pdf.

89. Gan, supra note 84 . 
those rights may still be subject to seizure and forfeiture under the CSA. Under the criminal forfeiture provisions, any "tangible and intangible personal property, including rights, privileges, interests, claims, and securities" are subject to forfeiture if the person owning it is convicted of a CSA violation punishable by more than a year in prison. ${ }^{90}$ The only other requirement is that the property be connected to the criminal activity in either of two ways: (1) it was part of the proceeds, or derived from those proceeds, obtained directly or indirectly as the result of such violation; or (2) it was used, or intended to be used, in any manner or part, to commit, or to facilitate the commission of, such violation. ${ }^{91}$ This applies quite easily to copyrights and patents. But trademarks pose an odd situation. While the federal registration could certainly be transferred to the United States under forfeiture, unless the government subsequently and consistently used the marks on goods and services in commerce, then the marks would be deemed abandoned and the registrations would lapse or terminate. Thus forfeiture in this case might seem a bit hollow, and amount to more of a destruction of the property. At the same time, it is not clear what the federal government would do with any cannabis IP-except of course for patents covering health or industrial applications. Under the civil forfeiture provisions, title to the IP itself might not be vulnerable, but any underlying "books, records, and research, including formulas, microfilm, tapes, and data which are used, or intended for use, in violation of" the CSA may be forfeited..$^{92}$

\section{State Intellectual Property}

State IP rights differ from federal IP rights in two important ways. First, they are only enforceable within the state in which they were secured. ${ }^{93}$ Second, they largely arise from use or other actions of the purported rights holder, and not from examination or registration by a state official. ${ }^{94}$ Thus, trademark rights generally arise as a matter of common law when a mark is "used in commerce" on goods or services within a particular geographic area. ${ }^{95}$ Some states offer registration, but even in those states, rights can still arise simply through use in commerce. ${ }^{96}$ Trade secrets arise solely where purported owners take reasonable steps-generally seen as legal measures such as nondisclosure agreements and physical measures such as keeping information

90. 21 U.S.C. $\S 853(a)-(b)(2012)$.

91. $\S 853(\mathrm{a})(1)-(2)$.

92. $§ 881(\mathrm{a})(5)$.

93. Visintine, supra note 46.

94. Common Law Trademark Rights, BitLaw, http://www.bitlaw.com/trademark/ common.html (last visited Apr. 18, 2016).

95. Protecting Your Trademark, USPTO (2014), http://www.uspto.gov/sites/de fault/files/trademarks/basics/BasicFacts.pdf.

96. See John T. Cross, The Role of the States in United States Trademark Law, 49 U. Louisville L. Rev. 485, 512 n.129 (2011). 
about the secret in a secure location-to keep secrets that give a competitive advantage due to others' not knowing the information. ${ }^{97}$

But the lack of titling for state common law IP means that it is hard to determine whether such IP is subject to forfeiture under the CSA. What would this mean as a practical matter? What exactly would be seized? At the federal level, IP has formal title and substance such as issued patents, registered trademarks, and copyright registrations. Patents, in fact, expressly "have the attributes of personal property" under the Patent Act. ${ }^{98}$ These property-like titles, and their concomitant rights, can be bought and sold, and thus can be seized and forfeited. ${ }^{99}$ But what would it mean to say that common law trade secrets have been seized? Certainly, any documents codifying the trade secret can be forfeited. This forfeiture is implied by the civil forfeiture provision for "books, records, and research, including formulas, microfilm, tapes, and data which are used, or intended for use, in violation of" the CSA. ${ }^{100}$ The information contained within these media could then be disclosed publicly, destroying the trade secret. But destruction of the "property" is not forfeiture to the United States as the CSA expressly vests right, title, and interest in the government. ${ }^{101}$ Likewise, common law trademark rights, that are both hard to "transfer" and similar to federal trademarks, would lapse or terminate as abandoned if the federal government did not use them on goods or services in commerce. ${ }^{102}$

A final note on state trademarks: in the curious situation established by the federal-state tension on cannabis, state trademarks have come into unusual prominence. In conventional business channels, state trademarks are seen as inferior to federally registered marks. ${ }^{103}$ State rights are relied on only where federal registration cannot be obtained. ${ }^{104}$ But until the USPTO begins registering cannabis marks,

97. James Pooley, TRADE SECRETS the other IP right, WIPO MAG., Mar. 2013, at $2-3$, http://193.5.93.80/export/sites/www/pct/en/news/extracts/2013/wipo_magazine _03_2013_trade_secrets.pdf.

98. 35 U.S.C. \& 261.

99. Hartford-Empire Co. v. United States, 323 U.S. 386, 415 (1945) (explaining that it "has long been settled" that "a patent is property, protected against appropriation both by individuals and by government," as a result, courts have declined to issue antitrust decrees that "amount[] to a forfeiture of the patents").

100. 28 U.S.C. $\S 881(\mathrm{a})(5)$.

101. $\S \S 881(\mathrm{f}),(\mathrm{h})$.

102. $\S 881$ (e) (providing for transfer of the forfeited property); 15 U.S.C. $\S 1127$ (2012) (defining abandonment by reference to discontinuation of use "with intent not to resume such use").

103. Darryl C. Wilson, The Caribbean Intellectual Property Office (CARIPO): New, Useful, and Necessary, 19 Мich. ST. J. INT'L L. 551, 586 n.169; see generally Zvi S. Rosen, In Search of the Trade-Mark Cases: The Nascent Treaty Power and The Turbulent Origins of Federal Trademark Law, 83 ST. John's L. Rev. 827 (2009).

104. Charles E. Colman, An Overview of Intellectual Property Issues Relevant to the Fashion Industry, Aspatore, Jan. 2012, at *30, 2012 WL 167352 (explaining that "[s]tate trademark registrations are less logistically complicated and significantly less 
businesses must rely exclusively on state marks. At the same time, the intrastate-only jurisdiction of state trademark rights means that rights established in, say, Colorado, do not reach to Washington State. In the conventional scenario, the Colorado business would simply start using its marks on goods or services in commerce in Washington State and thus establish rights there too. But under the residency requirements for cannabis licensees in Washington State, ${ }^{105}$ a Colorado-based business, with no Washington State residents involved, could not engage in state-legal cannabis commercial activities in Washington. But then the Colorado company cannot establish Washington State trademark rights. Conversely, if it sought to establish and enforce state trademark rights in Washington, it would be at least tacitly, if not explicitly, admitting that it was violating Washington's I-502 and other drug laws. ${ }^{106}$ Thus, cannabis businesses seeking to establish multi-state, or even national, brands are finding significant challenges if they want to also stay on the right side of state-legal rules.

\section{B. Securities}

The second main category of intangible property we are considering is securities, which for our purposes include everything defined as a "security" under federal securities laws. ${ }^{107}$ Often generally clustered around the notion of an "investment contract," securities are used for businesses to secure capital in order to launch, grow, or transfer own-

expensive than their federal counterparts, but they also confer far fewer benefits, and thus are usually recommended only where one simply cannot afford to register a mark with the USPTO") (emphasis added).

105. See Wash. Rev. Code Ann. § 69.50.331(1)(c)(ii) (LexisNexis, LEXIS through 2015 3d Special Sess.).

106. As mentioned above, a cannabis business could seek to use Lanham Act Section 43(a) to show false designation of origin. Thus the Colorado business could pursue this tack and steer clear of claiming any use in commerce in Washington State. But as also discussed above, it is difficult to see a federal court enforcing such a claim.

107. The Securities Act of 1933 defines "security" as:

. . . any note, stock, treasury stock, security future, security-based swap, bond, debenture, evidence of indebtedness, certificate of interest or participation in any profit-sharing agreement, collateral-trust certificate, preorganization certificate or subscription, transferable share, investment contract, voting-trust certificate, certificate of deposit for a security, fractional undivided interest in oil, gas, or other mineral rights, any put, call, straddle, option, or privilege on any security, certificate of deposit, or group or index of securities (including any interest therein or based on the value thereof), or any put, call, straddle, option, or privilege entered into on a national securities exchange relating to foreign currency, or, in general, any interest or instrument commonly known as a "security", or any certificate of interest or participation in, temporary or interim certificate for, receipt for, guarantee of, or warrant or right to subscribe to or purchase, any of the foregoing.

15 U.S.C. $\S 77 b(a)(1)(2012)$. 
ership. ${ }^{108}$ While there have undoubtedly been many informal-and perhaps some formal-issuances of securities by cannabis businesses in the past, ${ }^{109}$ the state-legal systems of Washington State, Colorado, Oregon, and Alaska are already presenting the question of whether state-legal businesses in those states can go through conventional, above-ground issuances and transfers of securities.

Private offerings and sales of securities are likely already occurring. If they are structured appropriately as private offerings, then they are exempt from registering with the Securities and Exchange Commission ("SEC"). ${ }^{110}$ However, they may still need to register with state securities regulators. ${ }^{111}$ Presumably, securities regulators in state-legal jurisdictions will allow the registered offerings so long as regular offering requirements and disclosures are met. But the interesting question arises as to whether the SEC would attempt to block registration of a federal public offering. While the SEC does not technically have the authority to refuse to register an offering based on the nature of the securities or investment opportunity (so-called "merits review"), ${ }^{112}$ it does have a range of tools to delay or stay registration if it can show that the proposed disclosure by the issuer to accompany the offering is inadequate. ${ }^{113}$ It is also unlawful for any persons to engage in fraudulent stock offerings. ${ }^{114}$ Notwithstanding all of these, there appears to be no statutory authority for the SEC to delay or refuse to make effective the registration statement of a cannabis business that forthrightly discloses its activities, the nature of the investment, and the significant risks attendant to investment in an enterprise engaged in transactions that violate the CSA. Yet, we are hard-pressed to imagine the SEC making such a registration effective without trying to fight it.

108. Michael Lewis, 6 Things You Need to Know About Raising Capital for a Small Business, The Huffington Post (Aug. 23, 2013), http://www.huffingtonpost.com/ michael-lewis/6-things-you-need-to-know_b_3484069.html.

109. See generally Adrian A. Ohmer, Note, Investing in Cannabis: Inconsistent Government Regulation and Constraints on Capital, 3 Mich. J. Priv. EQuity \& VeNTURE CAP. L. 97 (2013).

110. Richard J. Morgan, Application of the Securities Laws in Chapter 11 Reorganizations under the Bankruptcy Reform Act of 1978, 1983 U. ILL. L. REV. 861, 863-67 (1978) (discussing the major exemptions to the SEC registration requirement).

111. Jennifer J. Johnson, Private Placements: A Regulatory Black Hole, 35 Del. J. CoRP. L. 151, 156-58 (2010) (discussing the legislative history of the National Securities Markets Improvements Act of 1996 and state regulation of securities prior to and coexistent with federal regulation). See generally Jonathan R. Macey \& Geoffrey P. Miller, Origin of the Blue Sky Laws, 70 Tex. L. Rev. 347 (1991) (discussing historical origins of state securities regulation).

112. See generally Daniel J. Morrissey, The Road Not Taken: Rethinking Securities Regulation and the Case for Federal Merit Review, 44 U. Rich. L. Rev. 647, 686-87 (2010) (criticizing the absence of federal merit review and proposing its implementation in the SEC).

113. See generally William R. McLucas, Stop Order Proceedings under the Securities Act of 1933: A Current Assessment, 40 Bus. L. 515, 521 (1985).

114. 15 U.S.C. $\S 78 \mathrm{n}(\mathrm{e})(2012)$. 
While we are unaware of any cannabis businesses' initial public offerings ("IPOs"), there appear to be some businesses that are reporting companies, trading on the so-called "pink sheets" and not on national stock exchanges. ${ }^{115}$ In these cases, the businesses either simply met the triggers that require SEC reporting whether the company desired it or not, or they were the product of "reverse mergers" in which the operating cannabis business is nominally acquired by a publicly traded shell, but then becomes the controlling interest of that shell. ${ }^{116}$ The apparent lack of cannabis company IPOs may also be due to the fact that state-legal businesses are only "lawful" within that state in which it is licensed. Further, residency requirements intentionally seek to make it impossible for any individuals or businesses to own state-legal cannabis enterprises in multiple jurisdictions. Thus, an SEC-registered, and thus presumptively national, public offering would be open to investors from across the country (if not the world), which could result in non-residents of the licensing state unlawfully becoming owners or beneficial parties of interest in the company.

Cannabis businesses contemplating an IPO may find a recent, cannabis ancillary business' IPO instructive. MassRoots, a social media app and marijuana advocacy hub, sought to register its IPO and, unsurprisingly, the SEC had concerns about declaring effective an IPO of even a cannabis-related business. ${ }^{117}$ After the SEC requested MassRoots declare whether the company believed they violated federal law, the company disclosed that "we may be deemed to be aiding and abetting illegal activities through the services that we provide to users and advertisers." 118 Following this response, the SEC moved on to different questions, ${ }^{119}$ thus implying acceptance of the answer. In the end, as MassRoots officers recount, the SEC had no authorized

115. Sam Becker, Here's How to Start Investing in Marijuana, CheAt SheEt (Feb. 21, 2015), http://www.cheatsheet.com/business/investing-in-marijuana-what-you-needto-know-before-jumping-in.html. Substantive analysis of cannabis-related stocks is also available on websites such as www.marijuanastocks.com.

116. This technique is also used by some foreign businesses to gain access to U.S. public capital markets where they might otherwise not qualify directly for various reasons. See, e.g., Nate Nead, GETTING HIGH ON MARIJUANA RTOS, INVESTMENTBANK, http://investmentbank.com/marijuana-reverse-merger/ (last visited Apr. 19, 2016).

117. James Joiner, The First Weed Tech IPO, Daily BeAst (Apr. 6, 2015, 5:25 AM), http://www.thedailybeast.com/articles/2015/04/06/the-first-weed-tech-ipo.html; see generally EDGAR Search Results, SEC (Mar. 14, 2012), https://www.sec.gov/cgi$\mathrm{bin} /$ browse-edgar? company=massroots\&owner=exclude\&action=getcompany \& Find=search (displaying SEC filings for MassRoots, Inc.).

118. Letter from Mark P. Shuman, Branch Chief-Legal, to Isaac Dietrich, Chief Exec. Officer, MassRoots, Inc. (Aug. 8, 2014), https://www.sec.gov/Archives/edgar/ data/1589149/000000000014040305/filename1.pdf; MassRoots, Inc., Registration Statement Under the Securities Act of 1933 (Amendment No. 3 to Form S-1) (13) (Aug. 26, 2014), https://www.sec.gov/Archives/edgar/data/1589149/00007217481400 0909/msrt082514s1.htm.

119. See Registration Statement of MassRoots, Inc. under the Securities Act of 1933 at 6 (June 13, 2014), http://www.sec.gov/Archives/edgar/data/1589149/ 
grounds for holding up the registration once it satisfied itself that the firm had disclosed all risk factors, especially including its potential illegal activities. ${ }^{120}$

It is unclear at this point whether the SEC will let this precedent drive it to also declare effective the IPO of an actual cannabis business-meaning one directly involved in producing or selling cannabis products-even where all appropriate disclosures of illegal activity are made. The Authors suspect that the SEC will try to draw another line. After all, would it-or should it-declare effective the IPO of universally illegal businesses such as heroin producers or dealers just because they fully disclose the illegality of their activities? And yet, it is hard to see where the SEC has clear statutory authority to do anything other than declare effective any registration fully complying with our federal mandatory disclosure securities system.

But perhaps this slippery slope of cannabis to heroin IPOs is illusory anyway: after all, the disclosures made to the SEC are public and are almost certainly admissible in court for criminal and civil prosecution. The heroin producers and dealers will have to have given their contact information, location, and essentially a road map of their crimes. Who is going to do that, especially when it seems highly improbable that any sane investor would even buy stocks offered in the IPO, so what is the point of staging the offering? The only reason the Authors are discussing cannabis IPOs, is because of the state-legal systems and the DOJ's uneasy and potentially temporary staying of its prosecutorial hand for a certain set of cannabis activities that are still very much illegal under the CSA. And the only reason that there may be a market for such an IPO is because some segments of the investing public are willing to bet that legalization is going to spread, and that the federal government will continue to stay its hand, and possibly even legalize or at least decriminalize in the not-so-distant future. The occurrence of some or all of those possibilities could cause cannabis company stocks to skyrocket, leading to sizable paydays for those who took the risk and "got in early." There is no similar set of current circumstances or future expectations for other illegal activities such as production or sale of hard drugs.

For purposes of this Article, however, the real issue is forfeiture of cannabis company stocks, whether procured through public or private sales. While the CSA civil forfeiture provision for "[a]ll moneys, negotiable instruments, [and] securities" $" 121$ may have been primarily drawn to valuable financial assets that a drug dealer had obtained as or from

000072174814000599/msrt061114s1.htm\#RiskFactor (discussing investment risk factors).

120. See generally, U.S. SEC, EDGAR Company Filings, http://www.sec.gov/edgar/ searchedgar/companysearch.html (last visited Apr. 19, 2016).

121. 21 U.S.C. $\$ 881(a)(6)(2012)$. 
proceeds, ${ }^{122}$ or by leveraging proceeds, from illegal activities, that statute is not so limited by its text. In other words, it is not only the securities of random third party companies that a drug dealer may be holding as part of his personal portfolio (and that can somehow be linked to "facilitating" those activities), but also securities issued by a company engaged in illegal activities and held by otherwise "innocent" external shareholders that seem to be subject to forfeiture.

Thus, cannabis investors will have to be aware of not only the conventional investment risk that a portfolio company might fail and its stock be rendered worthless, but also of the highly unusual risk that even if the business is successful, the federal government could come in at any time and seize all securities that facilitated the businessincluding those held by the external investors. Further, such investors likely could not successfully invoke any of the innocent holder or buyer defenses under the CSA, as they would almost certainly know that the company was involved in illegal activities. This would especially be true in any potential future public offering of cannabis stocks, due to the stringent disclosure requirements of the securities laws and SEC implementing rules. But it also indicates the reverse point: cannabis companies are going to have to be quite comprehensive in their risk-factor disclosures in private or public offerings. Further, one of those risks may well be that investors should know that they may be liable for aiding and abetting the criminal activities just from their investments - the normal liability shields limiting shareholders' exposure to just their invested capital likely provide no shield for aiding and abetting CSA violations by funding those who directly engage in them.

\section{Implications of Clouded Title for Cannabis Business Owners, Investors, AND Creditors}

As outlined above, most valuable cannabis business assets, as well as the investment securities issued by the company, are subject to criminal or civil forfeiture. And while the DOJ is currently holding back on prosecuting most of the state-legal businesses, this does nothing to remove the de facto clouded title to these assets that will continue until such time as the CSA is amended and/or "marihuana" is rescheduled or "descheduled" (removed entirely from CSA Schedules). ${ }^{123}$ In the meantime, this restraint itself may be making a more dangerous situation for cannabis business owners, investors, and creditors. By lulling these players into a newly emerging sense of "normalcy" around the state-legal cannabis industry, Congress and the DOJ's temporary reprieve may be encouraging these players to relax

122. See, e.g., United States v. Borromeo, 945 F.2d 750 (4th Cir. 1991).

123. Congress could amend the CSA to re- or de-schedule marihuana, or the DOJ could do so. 
their guard to some degree about the risks they are taking on. The state-legal systems themselves also facilitate this by enabling "clean well-lit places" that certainly look like conventional businesses.

But if a harsh reminder of the lurking property risks (not to mention prison sentences and fines!) is needed, cannabis industry players need only look at recent disorienting cases where insolvent cannabis businesses were denied the normal protections and processes of federal bankruptcy courts. In one case, a bankruptcy court denied Chapter 11 bankruptcy protections under the "clean hands" doctrine to a business that had violated the CSA by knowingly renting space to a marijuana business. ${ }^{124}$ In another, the bankruptcy court held that a Colorado couple who ran a state-legal marijuana business was not entitled to federal bankruptcy protection even though the couple's activities were in compliance with state law. ${ }^{125}$ Although there may be alternatives such as state receivership, the lack of bankruptcy protections is another factor that cannabis businesses, together with their investors and creditors, must consider.

Beyond the personal risk to owners, investors, and creditors, the clouded title issue also presents a systemic risk to the emerging cannabis industry. What other industry could launch and flourish where virtually all of the relevant business assets were held under clouded title? Is this not one of the primary problems that limit the development of entrepreneurship and industry in countries without adequate rule of law? In other words, where prospective business owners operate under legitimate fears that government agents will swoop in and seize inventory, assets, and real property at any time, can sustainable, longterm growth and mature industry arise? And what private citizens or institutions will invest, lend, or provide materials on credit in such an environment? Yet, this is essentially what society is asking our new state-legal cannabis industries and their investors, creditors, and suppliers to do.

Admittedly, this is at one level exactly the point behind the CSA and its forfeiture provisions: Congress wanted to make it extraordinarily difficult for illegal drug producers and dealers to engage in business - in other words, there should be no such thing as "business as usual" in these areas. But a number of states have spoken now, and even Congress has tentatively stayed the hand of the DOJ (which had already more or less restrained itself for the time being). ${ }^{126} \mathrm{~A}$ sense

124. In re Rent-Rite Super Kegs W. Ltd., 484 B.R. 799, 807 (Bankr. D. Colo. 2012).

125. In re Arenas, No. 14-11406, 2014 WL 4288991 (Bankr. D. Colo. 2014) ("The impossibility of lawfully administering the Debtors' bankruptcy estate under chapter 7 constitutes cause for dismissal of the Debtors' case under 11 U.S.C. § 707(a).”).

126. Cole Memo II, supra note 22. Congress, meanwhile, used a recent omnibus spending bill to continue prohibiting the DOJ from using funds to prevent states from implementing their medical marijuana laws. Jacob Sullum, Congress Did Not Legalize Medical Marijuana, Forbes (Dec. 31, 2015), http://www.forbes.com/sites/jacobsul lum/2015/12/31/congress-did-not-legalize-medical-marijuana/. 
that the federal government should at least allow these state experiments to run their course seems to have emerged across the country. But unless the intent is to sabotage such experiments, the federal government needs to find ways to allow the early pioneers of this new industry to operate in a reasonable facsimile of the normal business environment that other regulated industries enjoy. Otherwise, the various states-together with a complicit Obama Administration-will have simply created expensive, risky, yet doomed-to-fail ventures and regulatory systems. Let us instead seek to take best advantage of this experimental opportunity to see if legal and well-regulated cannabis markets can work and produce net social benefits. 
